\title{
MODERN AREAS FOR IMPROVEMENT OF UNIVERSITY STUDENTS' TRAINING
}

\author{
Olga V. STUKALOVA \\ Institute of Art Education and Cultural Studies, Russia
}

\begin{abstract}
The article aims to identify the relevant aspects of university students' multicomponent professional development. It was determined that professional development in higher education institutions promoted the ultimate personal resources. Prospective areas were identified for enhancing university students' professional training. Results are presented for the implementation of the developed model of pedagogical support for the professional development of university students. The pedagogical environment required for the implementation of the model includes the following aspects: integrated traditional and innovative teaching methods and techniques; balance between activities aiming to develop students' psychological, physical, intellectual, emotional and volitional needs; possibility to engage in independent and group creative and research projects and their presentation. The following types of pedagogical support were identified: the development of students' internal motivation for professional growth; support for various manifestations of the creative potential of an individual; promotion of interaction based on the constructive dialogue. Pedagogical support principles and their conceptual framework were described. Criteria were presented for students' advanced professional development. Overall, it was found that students' value-based attitudes towards their future professions change during their active involvement in independent creative and research activities which are also closely related to the learning process.
\end{abstract}

Keywords: modern students, pedagogical support, internal motivation, communication, professional training

\section{INTRODUCTION}

To respond to the challenges facing modern higher education and related to training highly competitive future professionals with high internal motivation, it is necessary to create favorable conditions for students to gain a holistic worldview, professional sustainability and rational goalsetting. Experience shows that internal motivation for self-development is a key incentive to students' professional development due to the fact that the content shifts, in their conscience, to personal meanings (Stukalova, 2017). Of special significance are pedagogical techniques aimed at developing students' awareness of their own professional goals and at internalizing their chosen professional mission (Ulyankina, 2001: 201-207).

The following researchers have examined professional personality development: V. I. Andreyev (Andreyev, 1996), G. M. Kodzhaspirova (Kodzhaspirova, 2003), Yu. N. Kulyutkin (Kulyutkin, \& Tarasov, 2001), I. Ya. Lerner (Lerner, 1987), A. M. Novikov (Novikov, 2000), P. I. Pidkasisty (Pidkasisty, 2005), Yu. P. Povarenkov (Povarenkov, 2002), V. A. Slastenin (Slastenin, 2000) and others. J. Guilford (Guilford, 1965) and V. V. Davydov (Davydov, 1998), who among others, conducted research on creative personality development.

Research works by D. B. Bogoyavlenskaya (Bogoyavlenskaya, 2002), V. N. Druzhinin (Druzhinin, 2004) and others highlight the following criteria for pedagogical support for future professionals and the indicators of high-level professional development:

- Positive internal motivation based on students' independent knowledge and skills acquisition;

- Ability to plan and organize activities, to think and act with sufficient freedom and independence, yet rationally and productively;

- Generalization skills;

- Flexible cognitive processes;

- Readiness for engagement in various types of activity (Van Driel, \& Berry, 2012);

- Goal setting, professional/creative commitment, determination (Rogers, 2016); 
- Good communication skills;

- Initiative;

- Self-organization;

- Diligence.

To develop these skills, students enrolled in professional training courses should have the opportunity to go beyond their habitual line of thought, to activate their emotional and volitional spheres and to make prompt and responsible decisions. This is supported by students' independent research and - at a larger scale - educational and cognitive activities that influence not only students' professional development in the university environment, but also their professional adaptation and skills upgrading in real life (Potashnik, 2010).

This study detected the following contradictions standing in the way of this obviously prospective area for improvement in higher education:

- Deficiencies in the structure of students' learning and cognitive activities: no step-by-step organization; poorly planned assessment benchmarks; priority of the event-oriented approach, when winning an academic competition turns out to be more important than ongoing, explicit work on assignments given by teachers.

- Psychological crises typical of students' age, including discrepancies between their perceptions of their "professional selves" and their profession, underestimation of their role in achieving success in a team project, etc.

According to the research conducted by B. G. Ananyev's school of psychological thought, it students' age is "a sensitive period for developing the main sociogenic capacities of an individual" (Ananyev, 2001).

The internal world of student-aged individuals acquires new features, their self-awareness increases and psychological processes change, and their emotional, motivational and volitional areas become more stable. Most researchers agree that, in order for students to get high-quality professional training, they should be provided with a possibility to obtain in-depth fundamental knowledge. At the same time, it is necessary to improve the quality of training by using innovative teaching methods and techniques designed to develop individuals' creative skills and to boost students' aspiration for continuous self-learning while taking into account their interest in self-realization (A. Verbitsky (Verbitsky, 1999), et al.).

The central psychological process in student-aged individuals is the development of their selfawareness, which includes the cognitive element (discovery of their ego), the conceptual element (perception of one's individuality) and the judgmental element (self-evaluation). The development of reflection creates conditions for a critical reassessment of preconceived values, hence, their modification and evolution.

All of the above-stated is to be taken into consideration when developing and implementing relevant and effective areas of professional university students' training nowadays. The article presents the results of a testing performed in these areas and offers guidelines on their implementation in higher education.

\section{MATERIALS AND METHODS}

Research Framework. Moscow State Institute of Culture, Academy of Water Color and Fine Arts of Sergey Andriaka, Moscow Pedagogical State University (Institute of Social Studies and Humanities), Moscow Art Theatre School, Gerasimov Institute of Cinematography, Smolensk Regional Institute of Culture and Arts, Smolensk State University, Petrozavodsk State Glazunov Conservatory. In total, 564 students and 43 teachers participated in the study.

Research Process. The first stage aimed to state facts (2012-2014). It included surveys directed at determining prospective students' expectations from professional university training (520 respondents). It was found that $78 \%$ of the prospective students have high expectations, showing dependency mentality and consumerism regarding professional university training. At the same time, they have rather poor general humanitarian knowledge: thus, $46 \%$ of the respondents were unable to

Submit Date: 01.07.2018, Acceptance Date: 25.08.2018, DOI NO: 10.7456/1080SSE/139

Research Article - This article was checked by Turnitin

Copyright $\mathbb{C}$ The Turkish Online Journal of Design, Art and Communication 
name major research works in the discipline they had chosen to specialize in).

Notions such as "professional mission", "professional commitment" and "self-determination" are not familiar to $67 \%$ of the surveyed prospective students, and they have difficulty in defining them. The knowledge component in professional training ranked as low as fourth in the main university training components. Contacts, relationships and the possibility of having a great time ranked first, followed by professional skills and student life. Overall, the expectations of the majority of prospective students for the learning process in higher education have little to do with reality and do not correspond to their pre-professional training.

The second stage (2015-2016) is a pedagogical observation and detection of problem areas in the course of professional training. To this end, surveys were conducted among university graduates, in addition to pedagogical observations. It was found that $76 \%$ of the respondents critically assessed their university training, with $44 \%$ of them replying positively to the question "If you had the opportunity to attend this university again, would you take it?" The reasons why university graduates would be unwilling to attend their university again are as follows:

- dissatisfaction with training organization (classes are dull and boring $-86 \%$; courses are not practice-oriented and it is sometimes hard to understand how they are applicable to future professional activities $-86 \%$; little time is allotted to independent projects $-68 \%$ );

- critical assessment of teacher-student relations $(68 \%$ of the respondents pointed to their teachers' indifference and $68 \%$ highlighted their incompetence);

- poor organization of learning activities $(88 \%)$.

The average of $36 \%$ of the surveyed university graduates answered affirmatively to the question whether they thought their professional training corresponded to modern requirements. At the same time, $42 \%$ of the surveyed university graduates were rather optimistic about their prospects for pursuing their profession, although part of the university graduates $(26 \%)$ was ready to work anywhere, provided they were well paid. Both university graduates and prospective students emphasized the importance of material assets (57\%) and 34\% were satisfied with the training received.

The third, forming, stage (2016-2017) included the use of didactic means for the pedagogical support during students' professional development. The universities focused on promoting the following areas of the students' professional development: unleashing the potential of practice-oriented independent research and learning activity; implementation of effective pedagogical techniques; interaction between traditional and innovative methods for training future professionals in the context of the humanization of higher education. The pattern of the pedagogical support model was implemented with a view to promoting the professional development of university students.

The fourth, verification, stage (2017-2018) was, above all, related to the monitoring of the evolution of the students' professional development. An assessment was made of the impact that the promotion of the students' learning activities had on this process. In addition to qualitative methods (interview, conversation, essay analysis, pedagogical observation, etc.), a number of qualimetric methods were also used, including the psychological burnout assessment survey, the Beck Depression Inventory, the methodology for assessing psychological activation, interest, emotional tonus, tension and comfort (Kurgansky and Nemchin), anxiety test (Spilberger and Khanin), method for detecting the extent of subdepression (Zung and Balashova) and Differential Emotions Scale (Izard), among others. The study also used critical thinking and social empathy methods.

\section{RESULTS}

The conducted study showed that students who were motivated to engage in research and learning activities felt less depressed and anxious. This result is also due to the promotion of a special cultural and educational environment in higher education and a focus on the developed model for the pedagogical support of the professional development of university students. The experiment revealed that the students' value-based attitude towards their chosen profession changed as a result of their active involvement in independent creative and research activity, which is also closely connected to the learning process (projects, festivals, conferences and so on).

The research highlighted the following:

Submit Date: 01.07.2018, Acceptance Date: 25.08.2018, DOI NO: 10.7456/1080SSE/139

Research Article - This article was checked by Turnitin

Copyright $\mathbb{C}$ The Turkish Online Journal of Design, Art and Communication 
- Pedagogical support principles, including the following components: structuring and selecting the content of students' learning and creative activities; shifting the content of independent research to the personal meaning dimension; setting up the learning environment in dialogue form; using modern teaching technologies; developing students' internal motivation to improve their professional skills.

- Criteria for students' development as highly qualified professionals: 1) in-depth knowledge of different fields of science; 2) special personal qualities; 3) specialized knowledge and skills improving the individual's professional and creative potential; 4) high motivation to engage in independent professional and creative activities. Besides, any modern professional should have a pronounced personal position and aspire to search for ways to improve and enhance his/her professional activities.

Some of the major factors in students' professional development are the internal significance of their profession, satisfaction with outcomes and with the activity itself. The present study developed and tested a model of pedagogical support to university students' professional development (Table 1). It was found that professional development consisted of specific stages, whose length depended on the external environment, the individual characteristics of students and professional development challenges. All parts of this model are interrelated and directed at achieving the main objective, i.e. improving the professional development of university students.

Table 1. Pedagogical model of student professional development in higher education

Objective: professional development of highly qualified future specialists directed at their personal growth and self-perfection

\section{Psychological and pedagogical nature of professional development:}

1)Domination of the idea of self-fulfillment when choosing a profession;

2)Existence of crises when receiving professional training and changing assessments of one's choice of profession;

3)Importance of creativity development;

4)Socio-psychological features of university students.

\begin{tabular}{|c|c|c|c|c|c|c|}
\hline \multicolumn{7}{|c|}{ Principles: } \\
\hline \multicolumn{2}{|c|}{$\begin{array}{l}\text { Interaction with the } \\
\text { process of cultural and } \\
\text { creative personality } \\
\text { development }\end{array}$} & & $\begin{array}{l}\text { Promotion of the } \\
\text { idea of professional } \\
\text { mission, professional } \\
\text { com mitment and } \\
\text { professional honor }\end{array}$ & \multicolumn{3}{|c|}{$\begin{array}{l}\text { Development of creative } \\
\text { activity, imagination, readiness } \\
\text { for responsible professional } \\
\text { decision-making }\end{array}$} \\
\hline \multirow{5}{*}{$\begin{array}{l}\text { H I } \\
\text { GHER } \\
\text { EDUC } \\
\text { A T I O } \\
\text { N } \\
\text { EN V I } \\
\text { R O N } \\
\text { MENT }\end{array}$} & \multicolumn{5}{|c|}{ Stages } & \multirow{5}{*}{\begin{tabular}{l}
\multicolumn{1}{r}{ H I } \\
GHE \\
R \\
ED U \\
C AT \\
I O N \\
EN V \\
I R O \\
N M \\
ENT
\end{tabular}} \\
\hline & \multirow{4}{*}{$\begin{array}{l}\text { P e d a g o g i c a l } \\
\text { situations, } \\
\text { Methodologies, } \\
\text { Techniques. } \\
\text { Technologies }\end{array}$} & \multicolumn{3}{|c|}{ Formation of the idea of profession } & \multirow{4}{*}{$\begin{array}{l}\text { Criteria: } \\
\text { Motivational } \\
\text { Cognitive } \\
\text { Communicative } \\
\text { Operational }\end{array}$} & \\
\hline & & \multicolumn{3}{|c|}{$\begin{array}{l}\text { Development of profession-related } \\
\text { personal qualities }\end{array}$} & & \\
\hline & & \multicolumn{3}{|c|}{ Professional self-determination } & & \\
\hline & & \multicolumn{3}{|c|}{ Professional excellence } & & \\
\hline
\end{tabular}




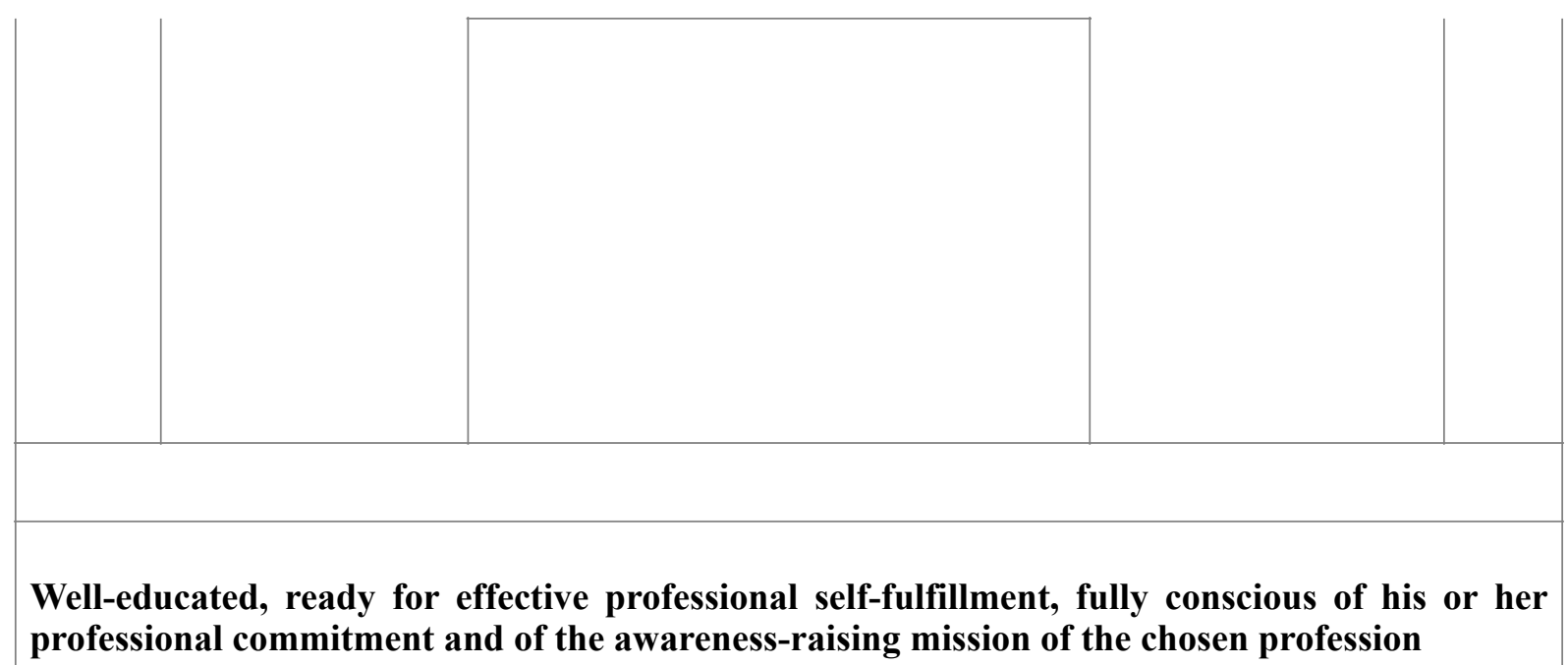

The following conceptual framework reflects the pedagogical conditions for the implementation of the above-mentioned model:

- The modern educational process shows a discrepancy between content, amount of training material and the quality of its acquisition, between the need to graduate highly qualified professionals and the established education system. Ensuring a high level of specialists' skills is impossible without a search for new areas contributing to the professional development of students.

- Professional training in higher education institutions should take into account the need for students to acquire basic professionally significant knowledge while creating conditions for developing their creative activity and imagination, intuition and motivation for selfimprovement, self-education and professional perfection.

- Professional development places emphasis on students' independent research and creative work.

- In their professional activities, university graduates should draw on their deep sense of personal and worldview attitudes, the value system and public service ideas.

The pedagogical framework of the model implementation includes the following:

- Integration of traditional and innovative pedagogical methods and techniques;

- Balance between sessions focused on the development of students' psychological, physical, intellectual, emotional and volitional spheres;

- Availability of students' independent and group work on creative and research projects and their presentation.

This process implied an efficient use of modern teaching techniques directed at developing students' leadership, independent research and communication skills (Groff, 2013).

An efficient implementation of this model also requires a qualitative shift in teacher-student interactions, including the following:

- horizontal organization of the educational process;

- expansion of the further education unit;

- ongoing monitoring of students' professional development (Kaldybayev, \& Beyshenaliyev, 2015);

- dialogization of the educational space;

- guidance on the pedagogical support for students;

- individualized approach to students;

- focus on students' independent research skills.

Importantly, assignments of reproductive nature stand in the way of practice-oriented education, of students' independence and responsibility and of their internal motivation to study (V. P. Zinchenko (Zinchenko, 1997)). 
Table 2 below shows the results of a diagnostic research (Stage 2) using various qualimetric methods: Ennis-Weir Critical Thinking Test, Social Empathy Method (N. P. Fetiskin, V. V. Kozlov, G. M. Manuylov (Fetiskin, 2002)), Emotional Intelligence Method (N. Hall), Information Culture Test (E. I. Rogov (Rogov, 1999)).

Table 2. Results of a study on the critical thinking, social empathy, emotional intellect and information culture of the students who participated in the testing of the model

\begin{tabular}{|c|c|c|c|c|c|}
\hline \multirow{2}{*}{ Indicators } & \multicolumn{2}{|c|}{$\begin{array}{c}\text { Group 1 } \\
\text { (Universities, Culture and Arts) }\end{array}$} & \multicolumn{2}{c|}{$\begin{array}{c}\text { Group 2 } \\
\text { (Pedagogical Universities) }\end{array}$} & $\mathrm{p}$ \\
\cline { 2 - 6 } & $\mathrm{M} \pm \mathrm{m}$ & $\partial$ & $\mathrm{M} \pm \mathrm{m}$ & $\partial$ & $\mathrm{t}$-criterion \\
\hline $\mathrm{CT}$ & $7.62 \pm 0.18$ & 2.61 & $6.1 \pm 0.19$ & 2.82 & 0.345 \\
\hline $\mathrm{SE}$ & $24.71 \pm 0.24$ & 3.49 & $25.85 \pm 0.18$ & 2.71 & 0.65 \\
\hline $\mathrm{EI}$ & $37.57 \pm 0.19$ & 2.81 & $28.75 \pm 0.17$ & 2.47 & 0.45 \\
\hline $\mathrm{IC}, \%$ & 48.38 & & 47.5 & & 0.078 \\
\hline
\end{tabular}

The results presented in the table show that both groups have an average empathy index $(24.71 \pm 0.24$ and $25.85 \pm 0.18$ respectively $(\mathrm{p}=0.65))$. According to Hall's method, these groups show a low emotional intelligence (EI) indicator $(37.57 \pm 0.19$ and $28.75 \pm 0.17$ respectively $(\mathrm{p}=0.45))$. The students' critical thinking skills are also low ( $7.62 \pm 0.18$ и $6.1 \pm 0.19$ respectively).

The study also analyzed the results of the Rokeach Value Survey and O. F. Potyomkina's Personal Socio-Psychological Patterns in the Motivational Sphere using ANOVA, a one-factor analysis of variance. Given its statistical reliability, it was found that pragmatic values, which correspond to the students' low professional development, are among the top-ranking elements in the hierarchical systems under investigation. Altruistic values, which correspond to the students' high professional development, are among the least important elements in the studied hierarchies.

The study showed that most first-year students do not establish any connection between the learning process and their chosen profession. Besides, first-year students often overstate their professional skills and this situation keeps worsening from year to year. Students have poor general academic knowledge, little expertise in targeted work with sources and limited vocabulary. As a result, they have difficulties communicating their intentions and expressing their thoughts and feelings. They also have an unfortunate tendency to think little about their professional objectives. The general conclusion is that first-year students are mostly adapting to the learning process and to the university environment without either understanding what professional development is or considering it personally important.

The study also carried out a correlation interpretation of the results obtained revealing that the following indicators of the students' professional development showed the highest correlation (r) rates:

- critical thinking skills $(\mathrm{r}=0.6841)$;

- emotional comfort $(\mathrm{r}=0.4280)$;

- $\quad$ social empathy $(\mathrm{r}=0.3534)$;

- tendency towards domination $(\mathrm{r}=0.3711)$;

- tolerance of others $(\mathrm{r}=0.3580)$.

The obtained correlation relations and reliable rates empirically prove how important and relevant critical thinking and readiness for independent knowledge acquisition are for the professional development of students. These characteristics demonstrate a close relationship between the major social and intellectual features of the professional development of students. Besides, the correlation analysis identified a speculative relationship between the students' professional development and their key socio-psychological qualities such as self-acceptance and adaptability.

The study undertaken and the final experimental results point to the need to develop and implement effective methods for pedagogical support of students, taking into consideration their individual

Submit Date: 01.07.2018, Acceptance Date: 25.08.2018, DOI NO: 10.7456/1080SSE/139

Research Article - This article was checked by Turnitin

Copyright (C) The Turkish Online Journal of Design, Art and Communication 
educational plan as well as age and personal peculiarities.

\section{DISCUSSION}

The professional development of future specialists is based on the following:

- cognitive restructuring of their conscience;

- shaping of types of motivational behavior;

- recognition of mistakes made in the course of their professional development and the need to correct them;

- self-identification in terms of specialization;

- involvement into a professional community and acquisition of the status of its full member;

- customization and awareness of individual creative strategies.

The greatest challenge in the professional development of students is developing their motivation to enrich their intellectual experiences, which also requires a well-thought pedagogical support.

The study identified the following directions in the pedagogical support of students' professional development:

- develop their internal motivation for growing professionally;

- support the manifestations of the creative potential of an individual;

- foster communicative interaction based on constructive dialogue principles.

It is confirmed that, in implementing the developed model in higher education, professional development activates key personal potentials, including the following:

- cognitive potential promoting the productivity of cognitive activities;

- moral potential assessed by moral and ethical standards, convictions, goals in life and worldview;

- creative potential manifesting itself in the focus of professional skill building on the structure of one's personal life plan;

- communicative potential that is evident in the ability to hold a constructive dialogue, to settle conflicts and to express one's ideas or creative plan in a convincing and sensible manner;

- personal potential that is determined by an individual's activity in building relationships in the professional environment and in outlining professional development needs in establishing them.

Development prospects in modern higher education are related to the increasing professional mobility of students, which shifts the focus of professional development to the acquisition of other related areas of knowledge. The study shows that this has a major impact on the development of students' world perception, deepens their intelligence, enriches their cultural experience and improves their language and self-learning skills.

\section{CONCLUSIONS}

This study defines the professional development of students as a dynamic, multidimensional and controllable process that takes into consideration the psychological and pedagogical dimension of professional training in a higher education institution. It is closely related to creative personal development and acquisition of cultural experience aimed at achieving high professionalism and motivating students to engage in continuous self-learning and self-perfection (Patton, Parker, \& Tannehill, 2015).

The structure of the professional development of students contains the following interrelated components: motivational (development of a student's internal motivation to uncover his/her creative potential); innovative (active acquisition and use of the latest technologies); organizational (development of a student's communication skills and readiness for a constructive dialogue) (Vangrieken, Meredith, Packer, \& Kyndt, 2017).

Overall, the study found that the current trend towards pragmatic education hinders, in fact, practiceoriented education, which is determined by changes in the content of education, its focus on the valuebased foundations of life and research, as well as the possibility of professional excellence. 
An important factor of the professional development of the future specialist in the area of culture and art is the combination of his/her professional self-perceptions related to self-esteem.

This factor contributes to the achievement of the internal coherence of personal and professional requirements, determines the nature and interpretations of the acquired professional experience as represented by positive and negative emotions and serves as a source of activity in terms of one's steps towards self-realization in future professional activities.

On the whole, the professional development of university students is a multidimensional process. In the context of evolving higher education, the dominance of the competence approach should be taken into consideration without overlooking the fact that the acquisition of specific competences is not a goal per se in higher education programs. Competences are just one of the manifestations of professional development that is immanent to the cultural and creative development of individuals (Jenkins, \& Agamba, 2013).

Student age is built around the identity process that consists of a number of social and individual choices, identification and professional development. In making these choices, an individual is guided by specific motives and the educational process in higher education institutions aims to shape his/her positive nature. The dominance of material motives cannot be the basis of personal and professional development. This is a secondary objective stemming from individual professional excellence. First, one becomes a real professional who is continuously expanding the scope of his/her possibilities, including theoretical training and academic research, and only then can he/she claim a high salary. Only this sequence of motives will develop young specialists' self-esteem and maintain their professional sustainability.

Professional development involves not only progressive stages, but also various types of activities (learning, learning and professional, early professional, research and professional and, finally, professional). Importantly, throughout the professional development process, students' shift from one period to another may go hand in hand with various crisis situations. As an example, it is not uncommon for university students finishing their first year, and particularly for second- or third-year students, to adopt a different attitude towards their professional skills development program. They get disappointed with their choice of profession and often think about applying to another educational institution or even about choosing a different area of specialization. Interestingly, students may start thinking about these changes despite their good academic performance and creativity shown in accomplishing success in assignments.

Therefore, a regressive movement is possible during the professional development process. University teachers, psychologists and students themselves should pay special attention to the first signs of such regressive situations. The knowledge of each student's individual progress and of his/her professional development process as well as each student's awareness of his/her personal qualities are indispensable for successful professional development.

\section{ACKNOWLEDGMENTS}

The findings were obtained as part of the implementation of the research project funded by the Ministry of Education and Science of the Russian Federation (27.7394.2017/8.9).

\section{REFERENCES}

Ananyev, B. G. (2001). “Chelovek kak predmet poznaniya” ["Man as an Object of Cognition”]. St. Petersburg, Piter.

Andreyev, V. I. (1996). "Pedagogika tvorcheskogo samorazvitiya" ["Teaching Creative SelfDevelopment"]. Kazan, Izdatelstvo Kazanskogo universiteta.

Bogoyavlenskaya, D. B. (2002). "Psikhologiya tvorcheskikh sposobnostey" ["Psychology of Creativity"]. Moscow, Akademiya.

Davydov, V. V. (1998). "Novy podkhod k ponimaniyu struktury i soderzhaniya deyatelnosti" ["A New Approach to Understanding the Structure and Content of Activity"]. Psikhologichesky zhurnal, 19(6), $20-28$.

Submit Date: 01.07.2018, Acceptance Date: 25.08.2018, DOI NO: 10.7456/1080SSE/139

Research Article - This article was checked by Turnitin

Copyright $\mathbb{C}$ The Turkish Online Journal of Design, Art and Communication 
Druzhinin, V. N. (2004). "Psikhologiya" ["Psychology"]. St. Petersburg, Piter.

Fetiskin, N. P. (2002). "Sotsialno-psikhologicheskaya diagnostika razvitiya lichnosti i malykh grup" ["A Socio-Psychological Assessment of Personality and Small Group Development"]. Moscow, Izdatelstvo Instituta Psikhoterapii.

Groff, J. (2013). "Technology-Rich Innovative Learning Environments. OECD: Innovative Learning Environments. Reports and papers". Retrieved August 17, 2018, from: http://www.oecd.org/education/ ceri/Technology-Rich\%20Innovative\%20Learning\%20Environments $\% 20$ by\%20Jennifer\%20Groff.pdf. Guilford, J. P. (1965). "Tri storony intellekta" ["Three Faces of Intellect"]. Moscow, Progress.

Jenkins, S., \& Agamba, J. J. (2013). "The missing link in the CCSS initiative: Professional development for implementation". Academy of Educational Leadership Journal, 17(2), 69-79.

Kaldybayev, S. K., \& Beyshenaliyev, A. B. (2015). "Kachestvo obrazovatelnogo protsessa v strukture kachestva obrazovaniya" ["The Quality of the Educational Process in the Structure of the Quality of Education"]. Uspekhi sovremennogo yestestvoznaniya, 7, 90-97.

Kodzhaspirova, G. M. (2003). "Istoriya obrazovaniya i pedagogicheskoy mysli" ["History of Education and Pedagogical Thought"]. Moscow, Vlados.

Kulyutkin, Yu., \& Tarasov, S. (2001). "Obrazovatelnaya sreda i razvitiye lichnosti” ["The Educational Environment and Personality Development"]. Novye znaniya.

Lerner, I. Ya. (1987). "Didakticheskoye osnovy metodov obucheniya" ["The Didactic Framework of Teaching Methods"]. Moscow, Pedagogika.

Novikov, A. M. (2000). "Rossiyskoye obrazovaniye v novoy epokhe" ["Russian Education in the New Era”]. Moscow, Egves.

Patton, K., Parker, M., \& Tannehill, D. (2015). "Helping teachers help themselves: Professional development that makes a difference". NASSP Bulletin, 99(1), 26-42.

Pidkasisty, P. I. (2005). "Organizatsiya uchebno-poznavatelnoy deyatelnosti studentov" ["The Organization of Students' Learning and Cognitive Activity"]. Moscow, Pedagogicheskoye obshchestvo Rossii.

Povarenkov, Yu. P. (2002). "Psikhologicheskoye soderzhaniye professionalnogo stanovleniya cheloveka" ["The Psychological Component of the Professional Development of an Individual"]. Moscow, Izd-vo URAO.

Potashnik, M. M. (2010). "Upravleniye kachestvom obrazovaniya: praktikooriyentirovannaya monografiya i metodicheskoye posobiye" ["Managing the Quality of Education: A Practice-Oriented Monography and Practical Aid"]. Moscow, Pedagogicheskoye obshchestvo Rossii.

Rogov, E. I. (1999). "Nastolnaya kniga prakticheskogo psikhologa" ["The Resource Book of Practicing Psychologists"], Vol. 2. Moscow, VLADOS.

Rogers, C. (2016). "Personality Development. A View on Psychotherapy". Moscow, Institut obshchegumanitarykh issledovaniy.

Slastenin, V. A. (2000) "Aksiologicheskiye osnovaniya obshchego i professionalnogo obrazovaniya" ["The Axiological Foundation for General and Professional Education"]. Lipetsk, Izdatelstvo Lipetskogo universiteta.

Stukalova, O.V. (2017). "The system of cultural and creative development of students in the educational environment of higher education institutions in the sphere of culture and art". Espasios, 38(56), 33.

Ulyankina, E. V. (2015). "Problemy adaptatsii molodykh spetsialistov v obrazovatelnykh organizatsiyakh" ["Addressing Adaptation of Recent Graduates in Educational Institutions"]. Akademichesky vestnik, 2, 201-207.

Van Driel, J. H., \& Berry, A. (2012). "Teacher professional development focusing on pedagogical content knowledge”. Educational Researcher, 41(1), 26-28.

Vangrieken, K., Meredith, C., Packer, T., \& Kyndt, E. (2017). "Teacher communities as a context for professional development: A systematic review”. Teaching and Teacher Education, 61, 47-59.

Verbitsky, A. A. (1999). "Novaya obrazovatelnaya paradigma $i$ kontekstnoye obucheniye: Monografiya" ["A New Educational Paradigm and Contextual Learning: A Monography"]. Moscow, Issledovatelsky tsentr problem kachestva podgotovki spetsialistov.

Zinchenko, V. P. (1997). "Obraz i deyatelnost" ["Perception and Activity"]. Moscow, Izd-vo Institut prakticheskoy psikhologii. 